УДК 327.37

\author{
P. A. Sinovets \\ Ph.D., Ass. Prof., \\ Department of International Relations, \\ Odessa I. I. Mechnikov National University, \\ r.32, French Blvd., 24/26, Odessa, Ukraine \\ Tel.: +30482633259 \\ E-mail: polina.sinovets@gmail.com \\ ORCID iD: http://orcid.org/0000-0002-5521-7982 \\ DOI: http://dx.doi.org/10.18524/2304-1439.2018.2(31).144302

\section{ENEMY AT THE GATES: CURRENT INTERNATIONAL SECURITY CHALLENGES AND THE NONPROLIFERATION ARCHITECTURE}

The latest decade turned to be critical for the Nonproliferation regime. The crisis of the security assurances, the growing role of nuclear weapons in politics as well as the emergence of the Nuclear Weapons Ban Treaty, trying to present the alternative to the NPT: all these trends threaten the stability of the Treaty and the integrity of the regime in general.

Key words: Nuclear Nonproliferation Treaty (NPT), Nuclear Weapons Ban Treaty (NWBT), Budapest memorandum, JCPOA, Russian Federation, North Korea, nuclear coercion, deterrence.

Basement of the Study. One of the most visible tendencies of the XXI century is the gradual decline of the global international security regimes. Created in the years of the Cold war they are still considered to be based on the post second world war system with its bipolar structure of international relations, number of poles and the distribution of influence between the actors.

Meanwhile the obvious discrepancy between the actual current development of the IR system and its formal superstructure presents the insufficiency of the latter, while showing up in the crisis tendencies, tractable everywhere. Still, one of the regimes, suffering from such discrepancy mostly is the nuclear arms control and nonproliferation. In particular the last decade turned to be most vivid in the number of issues demonstrating the incompatibility of the regime structure with the development of the international security architecture.

Our hypothesis is that these global structural challenges give certain ground as well as the explanation to the crisis within the NPT regime.

The aim of the research is to define to what extent the inconsistency of the current situation is able to affect the regime stability or it will finally contribute to the collapse of the NPT.

Analysis of Researches. Currently there are a lot of scholarly works defined with one or the other practical implications of the research, however very few ones are trying to integrate the effectiveness of the NPT regime functioning with consideration for the later trends in the field of international security. 
In particular, the issue of the safeguards and the position of Ukraine in the international NPT regime is brightly described by J. W. Knopf, S. Pifer, D. Yost $[12 ; 19 ; 25]$. Russian nuclear policy as well as its ideological background can be perfectly tracked in the publications of A. Arbatov, S. Karaganov, B. Tertrais $[1 ; 11 ; 22]$. The situation around North Korean nuclear program and its dynamics is widely researched by the number of analysts such as S. Sagan, A. Panda and V. Narang [20; 18]. While the Nuclear Weapons Ban Treaty is one of the newest research topics, being debated internationally in particular in the works of T. de Champchenelle, R. Davis Gibbons, A. Mount and R. Nephew and others $[6 ; 4 ; 16]$.

Meanwhile nor in the international science debates neither in Ukraine there is no integral research, dedicated to the theoretical implications which current tendencies are going to affect the NPT and the stability of its system. The current article makes some modest steps to start this discussion, developing the idea of the direct influence between the stagnation of the general security architecture and the collapse of the NPT regime.

The methodology of the research is based on the system analysis which permits to evaluate the challenges to the NPT regime combining the results of the three determined cases. While the methodology of studying cases includes content analysis of the official states documents, statistical analysis of opinion polls data as well as comparative analysis of the similar cases.

In general there are three tendencies having appeared this decade which, we believe, are eager to undermine the NPT regime.

First is the erosion of the important agreements, built in the framework on the NPT regime and having become functional due to the credibility of the promises given by the Treaty. In this connection the abrogation of the Budapest memorandum on the security assurances to Ukraine by Russia in 2014 as well as the unclear future of the Joint Comprehensive plan of Actions due to its decertification by United States should be mentioned. The crisis of such assurances agreements aimed at curbing proliferation is able to undermine the credibility of the NPT regime as the base of drafting such agreements. So at the end the issue of the security enhancement is fully directed to the hands of the state, while the existence of the powerful neighbors could ultimately push it for the reversal.

Second are the revival of the nuclear weapons 'coercive function and the increasing of their role as the effective tools of states' security policy. It has become a popular fashion starting from Russia's annexation of Crimea and its coercive threats to NATO to use nuclear weapons regionally [7]. Then kept been promoted by North Korea, having proclaimed nuclear weapons as the means of de-escalation and repelling the conflict. Presumably Koreans were inspired by the Russian path to use nuclear threats as a shield considering the fact that such shield credibly unties hands to the nuclear weapons owners in many other issues, besides the regime preservation. To some extent the spirit of the nuclear coercion was successfully supported by the US Trump administration in the growing tendencies of the nuclear policy development and the eagerness to react on Pyongyang challenge proactively. 
And the third is the introduction of the Nuclear Weapons Ban Treaty in the belief it would make the world better than rather on the opposite put it into the no global treaty space. Meanwhile the Treaty although calling the NPT as the cornerstone of the nonproliferation system does not oblige its members to sign and ratify the NPT, possibly providing a sort of the better alternative. In sum, at one point the world might find itself in the situation when one part of it will be the members of the Ban Treaty, providing more equal rights for the states, while the NPT will start becoming less and less relevant. This situation increases the risk of throwing the world into the chaos of the weak treaties, where none of them would be able to keep the universal balance.

The Ukraine and the Iran accords. In general it is worthwhile to agree with Marjana Bujerin who claims that there are not much in common between the Ukrainian and the Iranian cases, besides the obvious fact that they are both manifesting the «international community's efforts to maintain and enforce the international nonproliferation regime» and in both the United States has been the leading interlocutor" [3].

Still we can find some more similarities in the fields which can be important for the future legacy of the NPT regime.

Along with Russia, Belarus, and Kazakhstan Ukraine inherited nuclear weapons from the Soviet Union when it broke up in 1991. Unlike Belarus and Kazakhstan which quickly defined their non-nuclear path Ukraine did not take this option for granted. After the collapse of the USSR it faced the situation of becoming the third largest nuclear power after US and Russia according to the number of the Soviet nuclear weapons deployed on its territory (176 ICBMs, 1240 nuclear warheads and about 3000 tactical NWs). It is known that having promised to become a non-nuclear state in 1991, Kyiv de-facto came to this decision in late 1993. During this period of 1991-1993 it was often accused in pronuclear sentiments and the ambition to become a transitional nuclear state. Ukraine was blamed not only in blocking the capability of Russia to perform the launch of the missiles from its territory, but also in the unsuccessful attempt to acquire nuclear deterrence, failed due to the decisive influence of the NPT norms and the pressure of international diplomacy.

In fact, the situation was different enough. Having no full control over the Soviet nuclear weapons, deployed at the Ukrainian territory, Kyiv did not regard operational nuclear deterrence as viable tool of enhancing its national security. Since 1992 when tactical nuclear weapons were withdrawn from the territory of Ukraine, very few in Kyiv were seriously thinking on their military utility. At the same time politicians clearly understood the importance of deploying nuclear weapons at the Ukrainian territory. Besides their material value, which was estimated in billions of dollars, nuclear weapons were associated with the role of Ukraine as a successor of the Soviet Union and a certain bargaining asset in the deteriorating relationship with Russia. In particular, Russia clearly claimed for

Crimea, ignoring borders and even regarded military actions as an option to deprive Ukraine of nuclear weapons. So the primary security concern of Ukraine was how to deal with the brotherly nation to deter it without provok- 
ing. Here nuclear weapons occupied special role. Yuriy Kostenko, the head of the "nuclear hawks» lobby in Rada noted that «nuclear weapons perform defensive functions even if there is no control over it from the state it is deployed" [13, c. 28]. His opinion corresponded with the positions of some other parliamentarians, who believed that Russia wouldn't perform any aggressive actions till the last warhead left the territory of Ukraine. So, to some extent Ukrainian parliamentarians regarded nukes as catalytic tools able to raise stakes in the potential conflict with Russia therefore quickly causing the reaction of the outside powers interested to resolve it immediately.

Indeed, the United States played especially active role in disarming Ukraine by providing it with financial incentive as well as also involving Moscow into the more concessive dialogue with Kyiv. Therefore the Budapest memorandum of 1994 became the result of compromise and the intensive negotiations from both sides.

Formally Russia, United States and Great Britain assured Ukraine that they would keep its borders safe. They also assured that Ukraine would be keep its territorial integrity and also won't be attacked by nuclear weapons or any other means. In exchange Ukraine gave up all nuclear warheads and launchers, deployed on its territory and joined the NPT as non-nuclear state.

So, the incentives of nuclear disarmament overweighed pro-nuclear considerations. The most significant of them were: the possibility to integrate into the community of European democratic nations and the security assurances, provided by the great powers. The later gave Ukraine a hope to put a dot in the aspirations of Moscow for Crimea and the final delimitation of its Eastern borders.

Meanwhile the 2014 broke all Ukrainian illusions as for both. On one hand Russia annexed Crimea, and on the other started hybrid military activities at the East of Ukraine, keeping the state from any perspectives to integrate in NATO.

The situation with Iran started quite differently. Being the member of the NPT, in 2003 it was suspected in the development of the covert military nuclear program under the auspices of the civil nuclear activities, which Tehran was not interested to limit.

So, between 2006 and 2012 about 6 UN Security Council resolutions were adopted to prevent Iran from the military related procedures of its civil nuclear program: the uranium enrichment and the heavy water production. All of these resolutions were not fulfilled, as Tehran insisted on its sovereign right to pursue peaceful nuclear program according to the Article IV of the NPT.

The Iranian resistance was widely accompanied by its intimidating rhetoric as for Israel, claiming it should be "wiped off the map", its ballistic missiles program active development and the striving for regional hegemony. The state's nuclear program was associated with the progress of the Iranian nation, being the matter of pride from the side of the state's authority and the population.

During those years Iran was often involved in the negotiations as for the possible compromises over its nuclear program, still for many years it failed 
to come to consensus with the international community. Even in spite of the publication of the US intelligence report of 2007, which claimed that Tehran stopped pursuing nuclear weapons in 2003 the IAEA was founding some indirect evidences of the state's military nuclear activities, while official Tehran always denied it had any plans of a kind.

The situation deteriorated (as Iran was increasing the scale of the uranium enrichment year by year) till the European Union introduced comprehensive sanctions against the Islamic Republic. The economic crisis was one of the reasons why current President Rouhani was elected, as he promised effective negotiations on the Iranian nuclear program with the West. As the result, the Joint Comprehensive Plan of Actions (JCPOA) was signed in 2015 [9]. It has limited the Iran nuclear program to possible minimum, postponing the breakout time from the couple of months to a year and imposing severe control on any kind of nuclear activities in the country. On the other hand most of the economic sanctions were lifted from Iran for the time of the agreement implementation.

Generally the JCPOA was considered as a significant progress, evaluating the situation and the inherent risk that Iran could make positive decision as for acquiring nuclear weapons. It was signed between P5 states plus Germany and all the parties of the agreement considered to be equally important.

Meanwhile in October 2017, being not satisfied with the Iran's security policy in the Middle East, the US President Donald Trump decertified the JCPOA. The position of the European states was to stay in the deal still the withdrawal of Washington from the deal runs the high risk of eroding its credibility.

It is worthwhile mentioning that in spite of the obvious differences between the Budapest Memorandum and the JCPOA, there are some important similarities as for the future legacy of the NPT regime.

Firstly, the influence of the mentioned agreements on the credibility of the NPT regime. The fragility of these accords which, being the part of the universal system, turned to be based on the unilateral positions of the great powers, such as Russia and the United States. The annexation of Crimea caused the UN Security Council to gather (as it was supposed by the mechanism of the document), still there was not possible to reach the conclusion because of the Russia position, reasonably blocking any resolution. The United States and Europeans stay faithful to their obligations by the document, but Moscow's actions made the Memorandum de-facto invalid as well as the security assurances provided.

On the other hand, the decertification of the JCPOA by the United States left all other partners around the table, while it remains to be seen whether: 1) Europeans will be able to retain their trade with Iran in case if pressured by the United States to coerce Iran from its current military activities at the Middle East and Iran internal situation; 2) Iran will remain in the deal, as according to the Iran's President Rouhani said in case of US withdrawal from the nuclear deal, Iran's commitments 'would no longer exist' [8]. So, the survival of the JCPOA would remain under permanent question now. 
Secondly, the internal damage which the erosion of both accords created over the public opinion. For example, in the beginning of $1990^{\text {th }}$ when Ukraine was in the center of bargaining for the Soviet nuclear arsenal, not more than $33 \%$ of the population supported the retaining of nuclear weapons. And when Iran was under the international sanctions, about $34 \%$ of the population supported the idea to develop «nuclear power capabilities for military use» [23].

The drastic change can be visually tracked after the situation evolved and both deals were cancelled or tended to be cancelled. For Ukraine it was connected with the annexation of Crimea and the failure of the states 'obligations upon the Budapest memorandum to keep its borders secure. In particular, in $2014,49,3 \%$ of respondents believed that Ukraine had to restore the status of the nuclear weapons state, $27,7 \%$ were against [23]. Later in July 2017 according to the Institute of Sociology annual survey about $90 \%$ of respondents believed that had Ukraine retained nuclear weapons, the annexation of Crimea and the Donbas war would not have happened.

At the same time $55.4 \%$ of Iranians expressed support to their go ernment restarting nuclear program in case of the US withdrawal from the deal. Also the percentage of the Iranians, approving JCPOA as a good deal for Iran decreased since 2016 from $68 \%$ to $61,6 \%$ this summer [21]. It is still not much, but taking in consideration the possibility of the deal failure and the risk of sanctions return, those numbers would probably progressively increase.

Of course, the mentioned tendency can't be regarded as crucial in undermining the NPT regime, but it is one of the many stones which the present decade has damaged more or less successfully in a fence of the global regime.

The growing of NW role as a policy tool. In September this year the official representative of Russian ministry of foreign affairs explained the global denial of the nuclear arsenals - as a «non-serious and even an irresponsible step». The reason is that «nuclear weapons are objectively one of the pillars of international security" [10]. In fact it was the summing up of the Russian worldview based on the assessment of nuclear weapons as a background for Russian uprising.

Today Russia is waging sort of a Cold War with the West for the restoration of its greatness, as it perceives it. And in this war nuclear brinkmanship presents the important element of the strategy: to restore the division of Europe for the spheres of influence as it was during the times of the Soviet Union.

After the breakup of the Soviet Union Russia found itself in the total economic decline, the drastic loss of influence in the world and social collapse. The only two elements which kept it still superpower's conscience at the level of greatness were superpower nuclear arsenal and the permanent place at the Security Council, but the later was similar to the French and British and the Chinese positions. At the meantime nuclear weapons remained on the level of the assured destruction with the world hegemon, the United States. So, it is not surprising that a decade later when Russia started gradually to recover from the economic and social hardships the first which dictated it «the appropriate behavior» was nuclear arsenal. It was at once after Russian political 
defeat over Kosovo, so the first revanchist ambitions were embodied into the text of the Military Doctrine 2000, which in fact, being slightly changed in the later Military doctrine versions is still viable for Russian nuclear policy. The idea to use nuclear weapons in the situations «critical for the national security», prescribing it for the regional conventional war was the main novelty of the doctrine. Later the West called it «the escalation for de-escalation strategy", as nuclear weapons were aimed to deter any strong power to interfere in Russia's conflict with its neighbors [5]. In 2014 Moscow changed the conditions of the nuclear weapons use to "when the existence of the state is under threat», still not clarifying the character of the threat. While, talking to the experts it is quite possible to understand that «the existence of the Russian state" is also a very wide term, which, for example, may be attributed even to the attempts of NATO and Ukraine to bring back Crimea by the threat of force [17].

Moreover, one should not forget about the concept of the limited strategic nuclear strikes, which was developed by the Russian ministry of Defense in 2003 and in spite of its absence in the texts of the official Russian doctrines in 2010 and 2014 has never been officially denied. To some extent the situation can be even more complicated as Russian nuclear forces are usually deployed together with the conventional ones, so any military attack over conventional Russian forces might be easily interpreted by the Russian authorities as the strategic counterforce strike, causing a nuclear response. The credibility of this option can be emphasized by the fact that Russian RS-28 «Sarmat» ICBM which is to be deployed in the next couple of years in fact by design is not supposed to survive the nuclear attack, therefore can be considered as a first strike weapon [15].

One can suggest that Russia enjoys this sort of nuclear ambiguity, having in mind the "threat which leaves something to chance» and therefore makes the opposite side to be much more cautious than it could be out of this threat.

Describing the importance of nuclear weapons for Russia Sergey Karaganov directly points out that in 1990 when Russia actually denied nuclear deterrence, it got conflicts in Iraq, Libya, Syria, namely the former sphere of influence of the Soviet Union. Still in 2010 using nuclear coercion Russia «stopped the expansion of the Western allies in Crimea ... and blocked the chain of the regime changes" [2]. So, in fact Russia regards nuclear weapons as basic and indispensable element of its influence.

Mainly this and the fact that regional war stayed among the cases of the potential nuclear weapons use along with the intimidating nuclear rhetoric and the intensive testing/deployment of arms permitted to regard nuclear weapons as a primary tool of Russian coercive policy towards the West.

This decade was also marked with the uprising of the relatively new nuclear actor which is North Korea. Namely, Pyongyang honestly tried to join the nuclear club since 2003 when it had abandoned the NPT still it took the state about a decade to prove the existence and the efficiency of its nuclear weapons. In fact, the range of aggressive signals Pyongyang sends to the word can even compete with the Russian ones at least in the dimension of nuclear 
and missiles testing and the attempts to prove the United States that they are also vulnerable in the face of Korean nascent nuclear arsenal.

The main question here is what stands behind the aggressive rhetoric and the increasing range of nuclear testing. Does North Korea follow the Russian path, understanding that nuclear weapons remain the most effective shield for the regime, even the one who is trying to change the world map?

Most of researchers conclude that the primary motivation of the DPRK is the survival of its regime, which started feeling itself very vulnerable after the overthrow of Hussein and Kaddafi. There is also an understanding that Pyongyang has the ambition to raise its political weight to wage more equal dialogue with the United States.

Still the main question is what are the long standing aims of the regime? Will it stop at the self-preservation or keep strengthening its positions to go further, towards the strategic goal of two Koreas unification? Trying to understand the aims of North Korea it's probably worth of not forgetting that states goals usually vary from the basic ones such as the regime survival up to those embedded in their constitutions and worldviews.

In particular, there is an idea that for Russia of $1990^{\text {th }}$ nukes played an existential role, as otherwise the interference of the West into its external conflicts such as war with Chechnya was imminent. The decade of 2010 has become the time when Russia started to argue and to take over its former spheres of influence.

Following this logic, DPRK may also start from enhancing its basic survival by deterring the enemies attack but later follow strengthening its military positions in the region to finish with the two Koreas reunification. In November 2017 the US administration interpreted the North Korea latest belligerent activities as the tool «to fundamentally change the status quo. Its primary goal... is to reunify with South Korea" [2]. In fact this is a very logical conclusion, as the idea of the final two Koreas unification is marked also in the Constitution of the North Korea.

Probably it doesn't mean that Pyongyang will pursue this goal as a shirt term one, while it is possible to expect that if ever the DPRK regime would acquire cart blanche to keep its nuclear weapons the next steps might be directed towards the reunification which will be the strongest test for the credibility of the US extended deterrence.

North Korea «can provoke a conflict in South Korea and then they can just basically put an ultimatum to the United States telling the Americans that if they get involved, they are going to basically get a North Korean retaliation strike», says Daniel Pinkston [11]. The expert also points out that the ultimate goal of the DPRK is the unification of the Korean peninsula on Pyongyang's terms to be recognized as a sole Korean state.

The other thing is to what extent these goals can become realistic and what measures the United States would have to use to contain North Korea from its prospective aggression. There is an experience of Pakistan who even with nuclear weapons failed to succeed in its revisionist objectives to join Kashmir. Still Pakistan was confronted with nuclear weapons and also conventionally 
more superior India. So, the North Korean nuclear challenge can be potentially balanced by the regional deployment of the US tactical nukes in South Korea and Japan as it was during the Cold war. The alternative variant is to keep the nuclear-capable bombers at Guam at high alert, which would still mean the return of nuclear deterrence to the world stage as the indispensable element of the security architecture [18, p.82]. This situation might theoretically work still the outcome for the future of nuclear disarmament (and the NPT regime in this regard) would be disappointing enough. All of the mentioned things mark the returning of nuclear weapons back to the stage as the active element of the international politics.

In sum, the tendency of reviving the coercive function of nuclear weapons used by Russia in 2014 might have the grave consequences for the NPT. First and foremost it adds political utility to nuclear weapons. This tradition was considered to fade away after the end of the Cold war when nuclear weapons started to look as more a symbolic than a political tool, pushing many to call them obsolete. So, since 2014 the practical demonstration of the nuclear coercion at play to a certain extent restored the reputation of nuclear weapons as the useful element of the hard power. On its own way North Korea might become the first who tried (and possibly would try) to implement the coercive experience of Russia, while those efforts would need the consistent response from the United States to keep the status quo. Most possibly this response will be also connected with deployment of nuclear weapons as the credible tool of deterrence of North Korean ambitions. Therefore the new century might successfully follow the traditions of the Cold war, where most of dividing lines between the military blocks and the opponents were drawn by nuclear weapons. The principal difference will be in the growing number of the nuclear actors and the consequent multiplication of the deterrence systems with the following complication and confusion of the deterrence interactions leading to the risk of inadvertent nuclear escalation.

The International Campaign to Abolish Nuclear Weapons. Besides the growing role of nuclear weapons in one side of the world there is a completely opposite tendency, in the other. The first international attempt to delegitimize nuclear weapons as a tool of politics is currently on its way. Its roots come from the success of the Ottawa Treaty (1997) which managed to be very efficient in stigmatizing and banning anti-personnel landmines. Inspired by this initiative the International Physicians for the Prevention of Nuclear War (the authors of the Ottawa Treaty) in 2006 launched the International Campaign to Abolish Nuclear Weapons (ICAN) [14]. The main idea was following the example of the Ottawa Treaty to underline the inhumane character of the nuclear weapons, stigmatizing them similar to the land mines.

The ICAN efforts ended up with the long expected event - the signing of the UN Treaty over the Prohibition of Nuclear Weapons which has opened for signature on 20 September, 2017.

First time in the history the treaty has forbidden states not only possess nuclear weapons, but also "allow any stationing, installation or deployment of any nuclear weapons ...in its territory» (Art 1.g), «to use or threaten with 
nuclear weapons use» (Art.1. d) and to «....receive any assistance from anyone to engage in any activity... prohibited under this Treaty» [20]. Therefore the Treaty is forbidding not only the use of nuclear weapons, but even the nuclear sharing policy and the nuclear deterrence which is considered to be one of the most influential policies in the years of the Cold War. Still, trying to introduce such revolutionary developments in the international affairs, the Nuclear Ban Treaty presents quite a contradictory event for the nonproliferation regime.

First of all the Treaty looks weak as for the mechanism of verification it is referring to. In particular it reminds «competent international authority designated pursuant to paragraph 6 of this Article for the purpose of verifying the irreversible elimination of its nuclear-weapon", the body which is to be formed in the future. One of the biggest problems that this body won't be built on the universal ground not including most of the states having an expertise in the nuclear weapons programs, except South Africa, who can't probably form the international verification body on the unilateral ground.

Secondly, it forbids the idea of nuclear deterrence, thus closing the doors for the non-nuclear states who base their security at their allies 'nuclear umbrella as well as the doors of the conference on disarmament as the forum of expressing different positions.

And thirdly, it sounds a bit outdated in a way of addressing concerns.

The Nuclear Weapons Ban Treaty is something which should have been introduced in the middle of XX century, right after the bombings of Hiroshima and Nagasaki, when the antihuman character of nuclear weapons was more than obvious. It happened only 72 years later moreover it happened in the world where nuclear weapons have never been applied any time again. This situation is very different from the situation with conventional weapons, which cause many deaths every day all over the planet.

In this connection the probability of NBT to follow the destiny of the Ottawa Treaty looks bleak enough. On one hand nuclear weapons does not bring the regular direct damage to the humans as the land mined did, but on the other the land mines had never had the reputation of the weapons, eager to influence directly the results of the war. And what is more important, the weapons able to avoid the war by their overwhelming deterrent effect.

The greatest opportunity the Nuclear Weapons Ban Treaty introduces is the establishing of the international norm, forbidding nuclear weapons. Still the conditions and the situation in which the Treaty was introduced are mostly demonstrating the fact how the commonly accepted moral norm lacks credibility for the international politics. Meanwhile the number of the Treaty signatures - just 53, while among the parties signed there was no Japan, who actually suffered from nuclear weapons, neither Ukraine who, as we mentioned earlier presents one of the loudest cases of nuclear disarmament. Moreover, among those 53 states who signed the Treaty, only 3 states have ratified it at the moment. The reason is probably the strongest belief in nuclear deterrence. Japan relies on the extended deterrence of the United States, which has become even more vigorous for the state since the nuclear 
awakening of the North Korea. Ukraine demonstrates its solidarity with the extended deterrence of NATO and the full lack of confidence towards the international treaties. Both Sweden and Switzerland still haven't gained the support of their parliaments. Unfortunately this is the situation when common moral norms value is neglected in favor of the value of deterrence gives the worst prospective not only for the real implementation of the TPNW, but also for the legitimacy of the Article 6 of the NPT.

Moreover, TPNW tries to take the disarmament lead from the NPT, referring to "the slow pace of nuclear disarmament» and suggesting the better alternative for those states who consider the NPT not equal and not moral enough. In spite of the fact that the Treaty was presented as the attempt to strengthen the NPT norms there is no article obliging its members to join the Nonproliferation Treaty. Therefore it actually presents not the support, but the «extra blow to the NPT, already weakened» [4]. The Ban Treaty forms the alternative reality for the NPT, which would be not strengthened but weakened because of the fact that the new Treaty provides more equal opportunities for the members, here demonstrating its obvious superiority over its predecessor. In this situation the Ban Treaty presents the form of a protest over the NPT, which considering all other challenges is probably not an appropriate moment.

The weakest feature of the NPT as it is built is the spirit of inequality, but on the other hand the different conditions, provided to the different states to certain extent reflect different interests of the states. Therefore the NPT turned to be able to align the realistic perceptions of the nuclear states and the allied nations with the liberal institutional agenda of the non-nuclear states.

The Nuclear Ban Treaty does not consider this variety of the states' basic conditions, therefore stands contradictory to the existing international system.

Nuclear Ban Treaty forbids nuclear deterrence as the policy, therefore leaving no place for the nuclear sharing policy within NATO as nuclear alliance. This situation might be really dangerous not for such authoritarian states as Russia or North Korea, but for the democracies such as Netherlands, Great Britain or France, where the political development is defined by the public opinion and support. So, hypothetically the more democratic and equal Ban Treaty might create "the norms cascade" while more and more democracies will join it eroding the NPT from inside by changing the positions of the core nuclear states [24]. Of course the denomination of nuclear deterrence is the good news for the supporters of TPNW meanwhile it will progressively weaken the NPT, the later as insufficient and double-standard agreement, as nuclear deterrence is invisibly embedded into the Treaty text. At the same time it won't be able to take the nuclear sword away from the hands of the authoritarian states [6].

Moreover, the risk of Ban Treaty introduction is that it may polarize both communities of the nuclear disarmament believers and the nuclear deterrence advocates. As the result, on one hand it will create "the forum- shopping", 
when certain states will consider joining the nuclear weapons ban treaty as the enough nonproliferation measure, therefore eroding the NPT [5]. And on the other the norm of nuclear disarmament will be subjected to the Ban Treaty supporters, while the NPT will be transferred into a Treaty of the deterrence policy, again leaving the ideals of disarmament far away behind. This situation will hardly be useful for the credibility of the nonproliferation as a norm as it will be deprived of its universality as based on the global balance of interests.

In sum, the world might find itself facing two options, while both of them are not attractive for the nonproliferation in general. On one hand it can be a split between the fading NPT and the Treaty, turning to be powerful enough to challenge the NPT but not as comprehensive to become global. As the result both treaties won't have a comprehensive effect, while pushing the states to stay away from the nonproliferation security architecture.

Still the highest probability is that Ban Treaty won't be able to become a full-fledged document, leaving this function to NPT while its ineffectiveness will prove the incompatibility of morale with politics, bringing the general disappointment in the high moral values embedded in the NPT.

Conclusions. During its history the regime of nuclear nonproliferation survived many challenges and managed to stand. Probably the main reason is the fact that the Treaty itself is formed at the balance of interests combining security concerns of nuclear states and their allies with the assurances for the non-nuclear ones. Therefore the NPT regime presents the sort of the compromise between the interests and the principles being flexible enough to satisfy most of its parties.

The later decade presents the number of challenges which altogether run the risk to weaken the NPT due to the range of contradictory tendencies:

1. One of the key security problems today is the progressing discrepancy between the actual current development of the security environment and its formal security structure, lagging behind. Being formed during the Cold War those security structure is mostly standing at the bipolar system of the international relations while the new system shows more and more multipolarity. As the result the security structure suffers from not only the lack of efficiency, but also the lack of credibility, which is demonstrated in the multiple international crisis tendencies. To some extent it is possible to understand as the NPT regime presents one of the showcases of the gradual IR system decline resulting from the incompatibility of the obvious security environment and its formal structures.

2. The weakening of the mechanism of assurances, which NPT regime gives to a state in exchange to keeping the nonproliferation path. The experience of Ukraine and Iran showed that the normative power of the NPT and the based on treaties is limited enough, at least in cases where the interests of the powerful states were involved. As the result the dynamic of the public opinion showed certain increase of the pronuclear moods as well as the general disappointment in the power of the NPT regime. The latter is probably more important as it shows the limitations of the regime where it comes to the hard 
power issues, eroding the idea of norms protection, provided by the liberal theories of international relations such as the NPT regime. As the result the mentioned cases may lay the ground for the decreasing credibility of the NPT as the security mechanism for those states who were seeing them protected by the assurances system, provided within the regime.

3. This situation is significantly aggravated by the relative effectiveness of the nuclear coercion/ deterrence policy, demonstrated by such states as Russia. Being able to annex the Crimea (to certain extent due to the coercive power of its nuclear weapons) Moscow showed the undeniably inspiring example to the states, having nuclear option in mind and already experienced the practical value of the nuclear choice bargaining. In particular, North Korea who "experimented» with the nuclear blackmail during the last two decades could not miss this chance. Besides the obvious benefits of regime preservation nuclear coercion might become a very tempting perspective for the Pyongyang in the future while cherishing the plans of two Koreas unification. And in spite of the fact that this may become the issue of the distant future, the necessity to build the strategy upon the future challenges will dictate the United States the expediency of using the nuclear counterweight at the Korean Peninsula and/or in the region. As the result the revival of nuclear deterrence as the active element of power projection in the XXI century makes the ideals, embedded in the NPT not as viable as it seemed at the end of the Cold war.

4. Moreover the appearance of the new Ban Treaty, trying to take a lead from the NPT in the field of nuclear disarmament and providing quite an unequivocal framework for this runs the risk to undermine moral positions of the NPT, showing its weak points such as: purely non-egalitarian character and the support of the nuclear deterrence as the norm in international politics. As the result the world might whiteness the split between the proponents of the Ban Treaty not only among non-nuclear states, but even among those nuclear who consider it more fair and those in favor of the NPT, supporting the norms of deterrence. In sum, the moral authority of the NPT will be undermined and it will turn into the treaty of the nuclear states and those protected by their nuclear shields. On the other hand there will be a club of the disarmament supporters, having a moral superiority, but lacking the universality because of the NPT deterrence supporters. And there will be the third way of the notreaty states such as India, Pakistan and Israel, who having nuclear weapons do not break any international regime and are not politically engaged. At the end, while having not universally accepted regime, more and more states might prefer to follow that third way of «non-alignment» with the NPT or the Ban Treaty while burring the global architecture of nonproliferation. 


\section{References}

1. Arbatov, A. «Beyond the Nuclear Threshold: Russia, NATO, and Nuclear First Use ELN Issue Brief: Arms Control». Europe an leadership network. October, 2017. Accessed April, 2017. https://www.europeanleadershipnetwork.org/wpcontent/uploads/2017/10/Beyond-the-Nuclear-Threshold.pdf;

2. Arbatov, A. and Acton, J. «Non-Nuclear Weapons and the Risk of Nuclear War: A Russian Perspective.» Carnegie Endowment for International Peace. Wednesday, November 29, 2017. Accessed March 7 2018. http://carnegieendowment.org/2017/11/29/non-nuclear-weaponsand-risk-of-nuclear-war-russian-perspective-event-5762

3. Bujerin, M. «Iran, Ukraine, and the global nuclear order.» Krytyka. August 12, 2015. Accessed August 12, 2015. https://krytyka.com/en/articles/iran-ukraine-and-global-nuclearorder

4. Davis Gibbons, Rebekka. «The Nuclear Ban Treaty, How Did We Get here, What Does It mean for the United States?» War on the rocks. July 14, 2017. Accessed July 14, 2017. https:// warontherocks.com/2017/07/the-nuclear-ban-treaty-how-did-we-get-here-what-does-it-meanfor-the-united-states/

5. Davison D., Poll. «Iranian Public Souring On Nuclear Deal, Rouhani.» Lobe Log. November 1 2017. Accessed November 1 2017. https://lobelog.com/poll-iranian-public-souring-on-nuclear-deal-rouhani/;

6. De Champchesnelle T. Vers L'interdiction des armes nucleaires ? Autor de L'attribution du prix nobel de la Paix a L'ong Antinucleaire ican.» Defense.gouv.fr. 2017. Accessed January 5, 2018. http://www.defense.gouv.fr/content/download/519522/8724411/file/NR_IRSEM_ n49_2017.pdf

7. Interview of President Putin. Krym: vozvrashhenie na Rodinu. Accessed March, 2018. https://www.youtube.com/watch? $\mathrm{v}=\mathrm{t} 42-71 \mathrm{RpRgI}$

8. "Iran to pursue «new path» if Trump ends the nuclear deal.» Iran daily. Acessed September 20, 2017. http://www.iran-daily.com/News/200922.html? catid=3\&title=200922;

9. Joint Comprehensive Plan of Actions, Vienna. 14 July, 2015. Accessed October, 2017. https:// www.state.gov/documents/organization/245317.pdf

10. Kamp, K. H. Nuclear Implications of the Russian-Ukrainian Conflict, 'NATO Response to Hybrid Threats.' Ed. By G. Lasconjarias AND J. Larsen, NDC, 2015.

11. Karaganov, Sergey. "O novom yadernom mire. Kak ukrepit' sderzhivanie i sokhranit' mir. «Rossiya v global'noj politike. Aprel 4, 2017. Accessed November 21, 2017. http://www. globalaffairs.ru/number/O-novom-yadernom-mire-18644

12. Knopf, J. W. Security Assurances and Nuclear Nonproliferation. Stanford: Stanford University Press, 2012.

13. Kostenko, Yu. Istoriya yadernogo rozzbroyennya Ukrayiny'. K.: Yaroslaviv Val, 2016.

14. Meixler, Eli. "Can a North Korean Missile Hit the U. S.? Here's What the Experts Say." Time. November 29, 2017. Accessed November 29, 2017. http://time.com/5040388/northkorea-icbm missile-launch-mainland-us/;

15. MID RF: zapret yadernogo oruzhiya protivorechit natsional'nym interesam Rossii.» Kommersant. Accessed October 5, 2017. https://www.kommersant.ru/doc/3409219

16. Mount A. and Nephew R. "A Nuclear weapons ban should first do no harm to the NPT.» The Bulletin of the Atomic Scientists. March $7^{\text {th }}, 2017$. Accessed march 7, 2017. https://thebulletin.org/nuclear-weapons-ban-should-first-do-no-harm-npt10599

17. Nuclear Posture Review, February 2018. Accessed February 15, 2018. http://www.ieee. es/Galerias/fichero/OtrasPublicaciones/Internacional/2018/US_Nuclear_Posture_Review_ Feb2018.pdf ;

18. Panda, A. and Narang, V. «North Korea and the Lessons From Pakistan.» War on the Rocks. Accessed November 21, 2017. https://www.realcleardefense.com/2017/11/21/north_korea_ and the_lessons_from_pakistan_298411.html

19. Pifer, S. "The Budapest Memorandum and the US Obligations." Brookings. December 4, 2014. Accessed December 4, 2014. https://www.brookings.edu/blog/up-front/2014/12/04/ the-budapest-memorandum-and-u-s-obligations/;

20. Sagan, S. D. «The Korean Missile Crisis. Why deterrence is still the Best Option.» Foreign Affairs. November-December 2017. 
21. Stavlennya gromadyan do vstupu v NATO i inshy'x py'tan' bezpeky'. Fond Demokraty'chni iniciaty'vy' imeni Il'ka Kury'chiva. Accessed December, 2016. http://dif.org.ua/ua/publications/press-relizy/stavlennja-gromadjan-do-vstupu-v-nato-i-inshih-pitan-bezpeki.htm

22. Tertrais B. «Russia's Nuclear Policy: Worrying for the Wrong Reasons.» Survival. $(60: 2)$ 2018.

23. Trilling, D. «Polling Iran: What do Iranians Think?» Journalist's Resource. Accessed October 17, 2017. https://journalistsresource.org/studies/politics/ads-public-opinion/polling-iraniranians-public-opinion-data

24. UN Treaty on the Prohibition of Nuclear Weapons.» ICAN. Accessed October 20, 2017.

25. Yost D. «The Budapest Memorandum and Russia's Intervention in Ukraine.» International Affairs. (91/3). 2015: 31-51.

Стаття надійщла до редакцї̈ 11.08.2018

\section{Список використаної літератури}

1. Arbatov A. Beyond the Nuclear Threshold: Russia, NATO, and Nuclear First Use ELN Issue Brief: Arms Control. Europe an leadership network. October, 2017. URL: https://www. europeanleadershipnetwork.org/wpcontent/uploads/2017/10/Beyond-the-Nuclear-Threshold. pdf (дата звернення: квітень, 2017).

2. Arbatov A., Acton J. Non-Nuclear Weapons and the Risk of Nuclear War: A Russian Perspective. Carnegie Endowment for International Peace. 29 november 2017. URL: http:// carnegieendowment.org/2017/11/29/non-nuclear-weapons-and-risk-of-nuclear-war-russianperspective-event-5762 (дата звернення: 7.03.2017).

3. Bujerin M. Iran, Ukraine, and the global nuclear order. Krytyka. 12 august, 2015. URL: https://krytyka.com/en/articles/iran-ukraine-and-global-nuclear-order (дата звернення: 12.08.2015).

4. Davis Gibbons R. The Nuclear Ban Treaty, How Did We Get here, What Does It mean for the United States? War on the rocks. 14 july 2017. https://warontherocks.com/2017/07/ the-nuclear-ban-treaty-how-did-we-get-here-what-does-it-mean-for-the-united-states/ (дата звернення: 14.07.2017).

5. Davison D. Iranian Public Souring On Nuclear Deal, Rouhani. Lobe Log. 1 november 2017. URL: https://lobelog.com/poll-iranian-public-souring-on-nuclear-deal-rouhani/ (дата звернення: 1.11.2017).

6. De Champchesnelle T. Vers L'interdiction des armes nucleaires ? Autor de L'attribution du prix nobel de la Paix a L'ong Antinucleaire ican. Defense.gouv.fr. 2017. URL: http://www. defense.gouv.fr/content/download/519522/8724411/file/NR_IRSEM_n49_2017.pdf (дата звернення: 5.01.2018).

7. Interview of President Putin. Krym: vozvrashhenie na Rodinu. 23 march 2018. URL: https:// www.youtube.com/watch?v=t42-71RpRgI (дата звернення: березень, 2018).

8. Iran to pursue "new path" if Trump ends the nuclear deal.» Iran daily. 20 september 2017. URL: http://www.iran-daily.com/News/200922.html?catid=3\&title=200922 (дата звернення: 10.09. 2018).

9. Joint Comprehensive Plan of Actions, Vienna. 14 july, 2015. URL: https://www.state.gov/ documents/organization/245317.pdf (дата звернення: 11.10. 2018).

10. Kamp, K. H. Nuclear Implications of the Russian-Ukrainian Conflict, 'NATO Response to Hybrid Threats.' Ed. By G. Lasconjarias AND J. Larsen, NDC, 2015. 313 p.

11. Karaganov S. O novom yadernom mire. Kak ukrepit' sderzhivanie i sokhranit' mir. Rossiya $v$ global'noj politike. 4 aprel 2017. URL: http://www.globalaffairs.ru/number/O-novom-yadernom-mire-18644 (дата звернення: 21.11.2017).

12. Knopf J. W. Security Assurances and Nuclear Nonproliferation. Stanford: Stanford University Press, 2012. $412 \mathrm{p}$.

13. Kostenko Yu. Istoriya yadernogo rozzbroyennya Ukrayiny'. K.: Yaroslaviv Val, 2016. $212 \mathrm{p}$.

14. Meixler E. Can a North Korean Missile Hit the U. S.? Here's What the Experts Say. Time. 29 november 2017. Accessed November 29, 2017. URL: http://time.com/5040388/north-koreaicbm missile-launch-mainland-us/ (дата звернення: 29.11.2017). 
15. MID RF: zapret yadernogo oruzhiya protivorechit natsional'nym interesam Rossii. Kommersant. 5 october 2017. URL: https://www.kommersant.ru/doc/3409219 (дата звернення: $5.10 .2017)$.

16. Mount A., Nephew R. A Nuclear weapons ban should first do no harm to the NPT. The Bulletin of the Atomic Scientists. March $7^{\text {th }}$, 2017. URL: https://thebulletin.org/nuclear-weaponsban-should-first-do-no-harm-npt10599. (дата звернення: 07.03.2017).

17. Nuclear Posture Review. February 2018. URL: http://www.ieee.es/Galerias/fichero/ OtrasPublicaciones/Internacional/2018/US_Nuclear_Posture_Review_Feb2018.pdf (дата звернення: 15.02.2018).

18. Panda A., Narang V. North Korea and the Lessons From Pakistan. War on the Rocks. URL: https://www.realcleardefense.com/2017/11/21/north_korea_and_the_lessons_from_pakistan_298411.html (дата звернення: 21.11.2017).

19. Pifer S. The Budapest Memorandum and the US Obligations. Brookings. 4 december 2014. URL: https://www.brookings.edu/blog/up-front/2014/12/04/the-budapest-memorandumand-u-s-obligations/ (дата звернення: 04.12.2014).

20. Sagan S. D. The Korean Missile Crisis. Why deterrence is still the Best Option. Foreign Affairs. November-December 2017.

21. Stavlennya gromadyan do vstupu v NATO i inshy'x py'tan' bezpeky'. Fond Demokraty'chni iniciaty'vy' imeni Il'ka Kury'chiva. 22 december 2016. URL: http://dif.org.ua/ua/publications/press-relizy/stavlennja-gromadjan-do-vstupu-v-nato-i-inshih-pitan-bezpeki.htm (дата звернення: грудень 2016).

22. Tertrais B. Russia's Nuclear Policy: Worrying for the Wrong Reasons. Survival. 2018. № 60 (2). P. 13-19.

23. Trilling D. Polling Iran: What do Iranians Think? Journalist's Resource. Accesseed October 17, 2017. URL: https://journalistsresource.org/studies/politics/ads-public-opinion/pollingiran-iranians-public-opinion-data (дата звернення: 17.10.2016).

24. UN Treaty on the Prohibition of Nuclear Weapons.»ICAN. 20 october 2017.

25. Yost D. The Budapest Memorandum and Russia's Intervention in Ukraine. International Affairs. 2015. № 91 (3). P. 31-51. 


\section{П. А. Сіновець}

кафедра міжнародних відносин ОНУ імені I. І. Мечникова

к. 32, Французький бул., 24/26, м. Одеса, 65058, Україна

\section{ВОРОГ БІЛЯ ВОРІТ: СУЧАСНІ ВИКЛИКИ МІЖНАРОДНОЇ БЕЗПЕКИ ТА АРХІТЕКТУРА РЕЖИМУ НЕРОЗПОВСЮДЖЕННЯ}

\section{Резюме}

Останнє десятиліття стала критичною для режиму нерозповсюдження ядерної зброї. Очевидні три основні тенденції, які помітно підривають стабільність режиму ДНЯЗ на сучасному етапі.

По-перше, це криза гарантій безпеки, що даються державам в обмін на їх ядерне роззброєння або утримання від ядерного вибору. 32014 року така тенденція наростає. 3 одного боку, в 2014 році світ став свідком порушення Будапештського меморандуму Росією шляхом анексії Криму і продовження гібридної війни на Донеччині. 3 іншого, вихід США зі Спільного плану дій з Іраном фактично поклав кінець існуванню СВПД і відповідно в черговий раз продемонстрував хиткість гарантій, даних державі з метою їі денуклеаризації під егідою режиму ДНЯЗ.

По-друге, зростання ролі ядерної зброї як елемента політичного тиску на прикладі Російської Федерації, для якої даний вид озброєнь сьогодні це не атрибут війни, а елемент повернення політичного престижу шляхом шантажу й утримання НАТО від відновлення порушеного Москвою status quo. Своєрідно російський шлях намагається повторити КНДР, розуміючи, що ядерний козир може стати не тільки запорукою виживання політичного режиму Пхеньяну, але і в подальшому створити основу для об'єднання Корейського півострова під егідою одного центру сили. Як результат, ядерна зброя набуває роль ключового елемента діалогу між КНДР і США, що, врешті-решт, здатне спонукати Вашингтон на розгортання своїх ядерних озброєнь в регіоні.

По-третє, поява Договору про заборону ядерної зброї (ДЗЯЗ), який пропонує шлях, альтернативний ДНЯЗ, що не тільки безпосередньо заявляє про неефективність останнього, а й загрожує розколоти його шляхом відвертої демонстрації дискримінаційного характеру документа. Як результат, очікувано зниження довіри до ДНЯЗ на тлі недостатнього підтримання ДЗЯЗ, що зрештою призведе до делегітимізації обох і вакууму договірної бази в сфері обмеження розповсюдження ядерної зброї і технологій.

Ключові слова: Договір про нерозповсюдження ядерної зброї (ДНЯЗ), Договір про заборону ядерної зброї (ДЗЯЗ), Будапештський меморандум, Російська Федерація, Північна Корея, ядерний примус, стримування. 


\section{П. А. Синовец}

кафедра международных отношений ОНУ имени И. И. Мечникова

к. 32, Французский бул., 24/26, г. Одесса, 65058, Украина

\section{ВРАГ У ВОРОТ: СОВРЕМЕННЫЕ ВЫЗОВЫ МЕЖДУНАРОДНОЙ БЕЗОПАСНОСТИ И АРХИТЕКТУРА РЕЖИМА НЕРАСПРОСТРАНЕНИЯ}

\section{Резюме}

Нынешнее десятилетие представляет собой достаточно критическое кремя для режима нераспространения ядерного оружия. Очевидны три основные тенденции, которые заметно подрывают стабильность режима ДНЯО на современном этапе.

Во-первых, это кризис гарантий безопасности, дающихся государствам в обмен на их ядерное разоружение либо воздержание от ядерного выбора. С 2014 года такая тенденция нарастает. С одной стороны, в 2014 году мир стал свидетелем нарушения Будапештского меморандума Российской Федерацией путём аннексии Крыма и продолжения гибридной войны на Донбасе. С другой, выход США из Совместного плана действий с Ираном фактически положил конец существованию СВПД и соответственно в очередной раз продемонстрировал шаткость гарантий, данных государству с целью его денуклеаризации под эгидой режима ДНЯО.

Во-вторых, возрастание роли ядерного оружия как элемента политического давления на примере Российской Федерации, для которой данный вид вооружений сегодня это не атрибут войны, а элемент возвращения политического престижа путём шантажа и удержания НАТО от восстановления нарушенного Москвой status quo. Своеобразно российский путь пытается повторить КНДР, понимая, что ядерный козырь может стать не только залогом выживания политического режима Пхеньяна, но и в дальнейшем стать основой для объединения Корейского полуострова под эгидой одного центра силы. Как результат, ядерное оружие приобретает роль ключевого элемента диалога между КНДР и США, что, в конце концов, способно побудить Вашингтон к развёртыванию своих ядерных вооружений в регионе.

В-третьих, появление Договора о запрещении ядерного оружия (ДЗЯО), который предлагает путь, альтернативный ДНЯО, не только напрямую заявляет о неэффективности последнего, но и угрожает расколоть его путём откровенной демонстрации дискриминационного характера документа. Как результат, ожидаемо снижение доверия к ДНЯО на фоне недостаточного пиетета к ДЗЯО, что в конце концов приведёт к делегитимизации обоих и вакууму договорной базы в области ограничения распространения ядерного оружия и технологий.

Ключевые слова: Договор о нераспространении ядерного оружия (ДНЯО), Договор о запрещении ядерного оружия (ДЗЯО), Будапештский меморандум, Российская Федерация, Северная Корея, ядерное принуждение, сдерживание. 